\title{
Representasi Tubuh Ideal Perempuan dalam Iklan Thermolyte Plus
}

\author{
Salsabila Aulia Putri \\ Program Studi Ilmu Komunikasi, Universitas Muhammadiyah Yogyakarta, Indonesia \\ Salsabila.a.isip19@mail.umy.ac.id \\ Arinda Novitasari \\ Program Studi Ilmu Komunikasi, Universitas Muhammadiyah Yogyakarta, Indonesia \\ Arinda.n.isip19@mail.umy.ac.id \\ Hasna Arsita Khoirunnisa \\ Program Studi Ilmu Komunikasi, Universitas Muhammadiyah Yogyakarta, Indonesia \\ Hasna.arsita.isip19@mail.umy.ac.id \\ Diserahkan: 27 April 2021; Direvisi: 28 Mei 2021; Diterima: 2 Juni 2021
}

\begin{abstract}
The background to this problem is the complexity of the standards of beauty in female figures. Women who are supported by having perfect visuals are a requirement for women to present their self-image. This study aims to describe the ideal body of women in the Thermolyte Plus advertisement. The ideal body of women is often represented mass media with different meanings, where this meaning is different from the actual meaning of the ideal body in women. The agreement that occurs in the community creates a perception of the meaning of the ideal female body according to what the media displays. In this study using a qualitative descriptive method with critical studies and also using the semiotic method to analyze the object of research. The result of this research is that the advertisement for Thermolyte Plus is representing an ideal woman must have a slim body without excess fat because a slim body will make women confident to appear.

Keywords: Ideal, Female, Representation, Body.
\end{abstract}

\begin{abstract}
Abstrak
Latar belakang masalah ini adalah kompleksitasnya mengenai standar kecantikan pada sosok perempuan. Perempuan yang ditunjang memiliki visual yang sempurna menjadi suatu tuntutan dalam perempuan untuk menampilkan sosok dirinya. Adapun penelitian ini memiliki tujuan untuk memaparkan mengenai tubuh ideal perempuan yang terdapat pada iklan Thermolyte Plus. Tubuh ideal perempuan sering kali direpresentasikan media massa dengan makna yang berbeda, dimana makna tersebut berbeda dengan makna sebenarnya tentang tubuh ideal pada perempuan. Kesepakatan yang terjadi dimasyarakat membuat adanya persepsi akan makna tubuh ideal perempuan sesuai dengan apa yang media tampilkan. Pada penelitian ini menggunakan metode deskriptif kualitatif dengan kajian kritis dan juga menggunakan metode semiotika untuk menganalisis objek penelitian. Hasil dari penelitian ini yaitu iklan Thermolyte Plus merepresentasikan bahwa sosok perempuan ideal wajib memiliki tubuh yang langsing tanpa lemak berlebih karena dengan tubuh langsing tersebut akan membuat perempuan percaya diri untuk tampil.

Kata Kunci: Ideal, Perempuan, Representasi, Thermolyte Plus, Tubuh.
\end{abstract}




\section{PENDAHULUAN}

Standar kecantikan yang ditujukan sebagai kedudukan bagi kaum perempuan yaitu suatu citra yang dikontruksikan sebagai sosok perempuan yang memiliki fisik yang sempurna, attitude yang baik serta penampilan yang dapat memuaskan indra pengelihatan. Tampil cantik dan sempurna menjadi suatu tuntutan dalam menunjang kepercayaan diri terhadap sosok perempuan. Di saat perempuan memiliki tubuh yang langsing, tinggi, putih bersih dan dengan wajah tanpa cacat dianggap sebagi sosok ideal yang dapat melakukan segala aktifitas dengan mudah.

Salah satu iklan yang memperlihatkan tubuh yang menjadi dambaan bagi setiap perempuan yaitu iklan dari Thermolyte Plus, pada iklan ini menampilkan secara jelas representasi ideal pada sosok perempuan mendapat value yang lebih dalam standar kecantikan. Thermolyte Plus merupakan suplemen penekan nafsu makan yang mengandung multivitamin, asam amino, mineral, dan herbal alami guna sebagai obat penurun berat badan. Adapun adegan pada iklan Thermolyte Plus yang memperlihatkan tiga orang perempuan yang mengaggumi bentuk tubuh seorang perempuan yang tetap ideal dan langsing padahal sudah memilki 2 orang anak karena telah mengonsumsi Thermolyte Plus.

Pada iklan tersebut ditampilkan bahwa tubuh langsing dan ideal pada standar perempuan adalah bentuk tubuh yang di tampilkan pada saat setelah mengonsumsi Thermolyte Plus. Iklan Thermolyte Plus menampilkan pesan bahwa mengonsumsi Thermolyte Plus dapat memberikan bentuk tubuh yang ideal. Dalam iklan ini ditampilkan perempuan dengan bentuk tubuh yang langsing, tinggi, dan berkulit putih. Berangkat dari ini, maka tujuan penelitian ini dilakukan untuk mengetahui representasi tubuh ideal perempuan dalam iklan Thermolyte Plus.

Beberapa penelitian terdahulu terhadap bentuk tubuh ideal perempuan dalam iklan dapat ditelaah sebagai berikut. Pertama, penelitian yang dilakukan oleh Putri dan Sabila, penelitiannya berkisar tentang representasi tubuh ideal perempuan dalam iklan WRP Versi Limited Edition. Penelitian tersebut menemukan bahwa tubuh ideal perempuan yaitu tinggi, langsing, dan berkulit putih. (Putri $\&$ Penulis, 2020).

Kedua, penelitian dilakukan oleh Firda dan Leadya dari Universitas Garut, penelitian yang berkisar tentang representasi citra perempuan dalam Iklan WRP Versi Limited Edition. Dalam iklan ini menggambarkan tentang bentuk tubuh ideal atau kecantikan versi iklan yang ditampilkan menjadi konsep bagi masyarakat bahwa konsep tersebut lumrah dan benar adanya. Penelitian tersebut menemukan bahwa perempuan yang memiliki tumpukan lemak di beberapa bagian tubuhnya dianggap sebagai sesuatu yang buruk atau tidak ideal sehingga menimbulkan rasa tidak percaya diri dalam mengeksplor dalam berbusana. (Nurfazrin \& Raturahmi, 2016).

Ketiga, penelitian yang dilakukan oleh Endah Muwarni, penelitian yang berkisar tentang konstruksi bentuk tubuh perempuan dalam iklan televisi. Penelitian tersebut menemukan bahwa bentuk tubuh ideal perempuan dikontruksi dalam iklan WRP. Perempuan diwujudkan dalam bentuk tubuh yang tidak hanya sekedar langsing tapi indah. Menonjolkan gaya hidup dan bentuk tubuh yang langsing, indah, dan sehat. Sehingga menciptakan suatu kewajaran dan keniscayaan bentuk tubuh ideal bagi perempuan (Muwarni, 2010).

Keempat, penelitian yang dilakukan oleh Ratih Puspa tentang isu ras dan warna kulit dalam konstruksi kecantikan ideal perempuan. Ratih meneliti tentang iklan pencoklat kulit (tanning lotion) yang telah dipilih dari dua majalah wanita asing (impor) yaitu majalah Marie Claire dan Glamour. Penelitiannya menemukan bahwa terdapat tiga wacana yang disampaikan oleh produsen produk tanning lotion (krim/cairan pencoklat kulit) melalui iklan-iklannya dalam mengkonstruksi kecantikan ideal perempuan: (1) kulit gelap diidentikkan sebagai simbol keseksian dan sensualitas. Perempuan yang mempunyai kulit berwarna gelap dipandang lebih seksi dan sensual, dan disebabkan lebih menarik secara seksual; (2) kulit gelap diidentikkan dengan kulit sehat karena sering terkena sinar matahari. Kulit yang sering terkena sinar matahari dianggap berkilau serta bercahaya, dan karena itu tampak sehat dan tidak pucat. Perempuan cantik adalah perempuan yang mempunyai kulit berkilau 
dan bercahaya, sehat karena sering terkena sinar matahari; dan (3) warna kulit gelap yang seksi dan sehat bukan hanya monopoli perempuan dari ras tertentu saja. Kini, semua orang bisa memilikinya (Puspa, 2010). Penelitian Ratih ini menarik karena menemukan bahwa bukan hanya kulit putih yang diidealkan, namun juga kulit berwarna coklat.

Terakhir adalah penelitian yang dikerjakan oleh Okta Pratiwi dan Luthfianiza. Meneliti tentang representasi identitas kulit perempuan ideal indonesia dalam iklan Citra, mereka menyimpulkan bahwa representasi perempuan berkulit putih yang sengaja dibentuk oleh media masih sangat kuat. Hal ini dibuktikan melaui konstruksi kecantikan yang dibentuk oleh media saat ini yang membuat banyak para perempuan menganggap bahwa kecantikan itu yang ditampilkan di media massa, di luar itu dianggap buruk. Tuntutan yang dibuat oleh media yang mengharuskan perempuan untuk memiliki kulit putih itu sangatlah menjadi tekanan (Pratiwi \& Luthfianiza, 2020). Berbeda dengan kelima penelitian di atas yang meneliti mengenai WRP, Smartslim, dan iklan pencoklat kulit, penelitian ini berfokus pada representasi tubuh ideal perempuan dalam iklan Thermolyte Plus.

\section{KAJIAN PUSTAKA}

\section{REPRESENTASI}

Menurut Stuart Hall, Representasi adalah proses bagaimana kita memberi makna pada sesuatu melalui bahasa. Untuk mempresentasikan juga berarti menyimbolkan, untuk mewakili, menjadi contoh, atau menjadi pengganti dari sesuatu. (Hall, 1997). Representasi dapat dilihat melalui tiga pendekatan. Yaitu Pendekatan reflektif, pendekatan intensional, dan pendekatan konstruksionis. Pendekatan reflektif melihat representasi sebagai penyampaian makna yang pemikirannya terletak pada objek, orang, idea atau kejadian yang ada di alam nyata. Pendekatan intensional melihat representasi sebagai suatu cara menyampaikan hal-hal khusus atau unik dalam melihat dunia. Sedangkan pendekatan konstruksionis memandang representasi sebagai pembangun makna menggunakan sistem representasional (Hall, 2003).

Menurut David Croteau dan William Hoynes dalam Wibowo (2013) menyatakan bahwa representasi merupakan hasil dari suatu proses penyeleksian yang menggaris bawahi hal tertentu dan hal lain dibaikan. Dalam representasi media, tanda yang akan digunakan untuk melakukan representasi tentang sesuatu mengalami proses seleksi. Mana yang sesuai dengan kepentingankepentingan dan pencapaian tujuan-tujuan komunikasi ideologisnya itu yang digunakan sementara tanda-tanda lain diabaikan. Maka selama realitas dalam representasi media tersebut harus memasukkan atau mengeluarkan komponennya dan juga melakukan pembatasan pada isu-isu tertentu sehingga mendapatkan realitas yang bermuka banyak bisa dikatakan tidak ada representasi realita terutama di media yang benar-benar "benar" atau "nyata" (Wibowo, 2013).

Menurut Richard Dyer dalam esainya mengambil dari Popular Television Seriously (ed. Lusted and Drummond, 1985), menggambarkan tipografi representasi:

1. Representasi ulang pada dasarnya terdiri dari bahasa media, konvensi yang digunakan untuk mewakili dunia audiens;

2. Menjadi perwakilan sejauh mana digunakan untuk mewakili kelompok sosial-juga termasuk dalam pertimbangan stereotip;

3. Siapa yang bertanggung jawab atas keterwakilan, bagaimana Lembaga membuat teks media untuk mempengaruhi dalam representasi- kebanyakan dalam representasi jenis kelamin, lakilaki yang menjadi perwakilan atau mewakili;

4. Apa yang audiens pikirkan menjadi representasi untuk mereka- audiens dapat memilih bacaan teks media yang berbeda dari yang ditawarkan.

Representasi media biasanya di produksi oleh institusi, mulai dari organisasi penyiaran besar atau perusahaan independent kecil. Bahkan novelis yang merupakan praktisi media yang sangat mandiri dan secara teoritis hanya dibatasi oleh konvensi generik yang digunakan, diterbitkan oleh organisasi besar yang pastinya memiliki pengaruh pada apa yang dihasilkan. Institusi media didominasi oleh kulit 
putih dan produksi medianya mencerminkan pada bias tersebut. Masyarakat western sendiri didominasi baik secara politik maupun ekonomi, oleh masyarakat berkulit putih sehingga sangat logis bahwa produsen budaya harus mencerminkan kelompok budaya tersebut dan membantu menciptakan kondisi hegemoni. (Sataloff et al., n.d.)

Representasi merupakan bentuk perwakilan dari cara pandangan masyarakat dominan kepada masyarakat lain sehingga membentuk cara pandang baru bagi masyarakat dalam memandang suatu fenomena. Dalam hal ini, representasi mengambil peran yang besar bagi apa yang diyakini oleh masyarakat terutama dalam media iklan. Seperti halnya apa yang akan dibahas dalam artikel ini bahwa iklan Thermolyte Plus merepresentasikan kaum dominan yang berkulit putih dan bertubuh langsing dan menjadikan kedua hal tersebut sebagai bentuk tubuh ideal yang harusnya dimiliki oleh masyarakat khususnya kaum perempuan.

\section{TUBUH IDEAL PEREMPUAN DALAM MEDIA}

Periklanan adalah wujud dari cara penyampaian pesan kepada khalayak, penampilan wanita dalam iklan akan lebih memikat secara virtual dalam menikmati pesan yang disampaikan dari iklan tersebut, dalam visualisasi yang ditampilkan iklan menimbulkan asumsi-asumsi terhadap citra perempuan yang ditampilkan, pencitraan perempuan bertubuh ideal ditampilkan dengan tubuh langsing. Media membentuk citra dengan merepresentasikan tubuh perempuan ideal sebagai makna dari simbol kecantikan pada umumnya.

Beberapa teori menjelaskan tentang permasalahan citra tubuh perempuan, sebagian besar peneliti mengemukakan pendapatnya terkait dengan pengaruh yang besar dalam membentuk dan mempertahankan masalah citra tubuh perempuan di masyarakat luas adalah karena faktor dari masyarakat dan budaya.

Disebutkan bahwa masyarakat luas sebagai penentu standar kecantikan perempuan dan perempuan yang menarik (Heinberg, dalam Thompson,1996). Dalam teori sosiokultural ini juga membahas peran penting media dalam penyampaian pesan yang mengaitkan tentang pemaknaan tubuh ideal, media dalam penyampaiannya memberikan informasi tentang bagaimana cara memperoleh tubuh yang ideal seperti pemakain suplemen, dan diet dengan deficit kalori, akibat dari itu semua banyak masyarakat luas terutama perempuan-perempuan berasumsi bahwa tubuh ideal yang ditampilkan dalam media mudah diperoleh dan hal tersebut memberikan stimulus dan pengaruh sikap mereka terhadap tubuhnya.(Thompon et al, 1999).

\section{METODE PENELITIAN}

Penelitian ini berusaha menjawab rumusan masalah tentang Representasi Tubuh Ideal Perempuan dalam Iklan Thermolyte Plus. Untuk mendapatkan jawaban yang berasal dari rumusan masalah pada penelitian ini dipakailah metode semiotika. Semiotika artinya teori bahasa yang diuraikan oleh Ferdinand de Saussure pada bukunya yang berjudul Linguistics Course in General(diterbitkan di tahun 1916 untuk pertama kalinya). Saussure menolak asumsi bahwa bahasa hanya mencerminkan fenomena serta sebaliknya menyarankan bahwa bahasa beroperasi pada sistemnya sendiri. Sistem ini menciptakan makna pada bahasa - makna tak berkembang secara alami atau unik. Ia mengatakan pendekatan ini semiologi, yang berarti studi perihal indikasi, namun kita akan menggunakan kata yang lebih umum untuk pendekatan ini, yang dikenal sebagai semiotika.

Tanda (kata) seperti 'tikus', contohnya, mempunyai dua sifat: suara dan gagasan. Namun tidak adanya korelasi antara suara dan ide: 'pilihan suara tertentu dibuat untuk menamai ide yang diberikan benar-benar sewenang-wenang'. Saussure menngungkapkan bahwa tanda bekerja menjadi suatu sistem, tanda-tanda (yaitu kata-kata) yang menghasilkan suatu bahasa mampu menandakan ide-ide secara tepat karena berbeda dari tanda-tanda lain: 'Bahasa ialah sistem kata yang saling bergantung di mana nilai setiap istilah dihasilkan semata-mata yang berasal dari kehadiran simultan dari orang lain. Jadi bahasa terstruktur melalui disparitas, dan pandangan baru yang tidak selaras bergantung 
pada bunyi yang berbeda, atau 'perbedaan fonetik yang memungkinkan untuk membedakan kata ini dari yang lainnya, sebab adanya perbedaan membawa makna' (Laughey, 2007).

Dengan ini, semiotika berkisar perihal studi tentang tanda dalam teks. Tanda (sign) meliputi dua aspek, yaitu penanda (signifiant), dan petanda (signified). Penanda bisa dimengerti menjadi bentuk/wujud fisik. Penanda dapat berupa bunyi, gambar, huruf, visual serta yang sejenisnya. Sedangkan petanda ialah konsep atau arti dari apa yang ditandai. Relasinya antara keduanya bersifat "diada-adakan" (arbitrary), dimana memiliki arti tidak ada relasi yang sifatnya alamiah antara penanda dan petanda. Semiotika dengan demikian merupakan relasi tripartit yakni tanda (sign) yang merupakan gabungan dari penanda (signifier) dan petanda (signified) (Hartley, 2003).

Selanjutnya, Saussure mengenalkan perihal langue dan parole. Langue adalah abstraksi dan artikulasi bahasa di taraf sosial budaya, sedangkan parole adalah ekpresi bahasa di tingkat individu. Agar lebih praktis dalam memahaminya, langue mampu kita sebut menjadi sebuah sistem bahasa yang berlaku, sedangkan parole adalah bagaimana individu berbahasa dalam sistem tersebut. Dengan demikian, maka parole terikat dengan langue.

Pemikiran Saussure mengalami perkembangan lebih lanjut oleh Roland Barthes. Barthes menyerahkn kontribusi krusialn lainnya agar memahami peran media dalam reproduksi ideologi. Barthes mengacu pada karya Saussure dan teorinya mengenai semiotika, yang telah memasuki dunia media serta penelitian sosial pada 1960-an. Beliau berpendapat bahwa pentingnya media dalam penyebaran ideologi atau pandangan dunia bertumpu pada kemampuan mereka untuk menyusun tanda dan gambaran dengan cara eksklusif. Dia meneliti cara di mana tanda-tanda (yaitu, gambar, kata-kata, musik, dan objek) memberikan makna yang lebih dalam di dalam masyarakat dan budaya daripada yang tampak secara lahiriah. Secara spesifik ia melihat media, melalui proses pemaknaan, membuat makna dan pandangan tertentu dalam masyarakat tampak natural dan masuk akal (Williams, 2003).

Pemikiran Barthes yang berjasa besar dalam memaknai tanda ialah tentang mitos. Gagasan pemikiran yang sebenarnya masih melanjutkan pengandaian Saussure tentang hubungan bahasa dan makna atau antara penanda dan petanda. Semiotika yang dibangun Saussure cenderung mengutarakan bahwa makna sebagai apa yang didenotasikan oleh tanda. Dengan demikian, tradisi semiotika di awal kemunculannya cenderung berhenti sebatas pada makna-makna denotatif alias semiotika denotasi.

Oleh Barthes, pendapat makna denotatif atau pemaknaan di tingkat utama (primary signification) dikaji lebih lanjut. Barthes menjelaskan bahwa terdapat makna lain yang justru bermain pada level yang lebih mendalam, yaitu di level konotasi atau pemaknaan sekunder (secondary signification). Dengan demikian, pemikiran Saussure dikembangkan oleh Barthes dengan membongkar praktik pertandaan pada tingkat konotasi tanda. Konotasi bagi Barthes justru mendenotasikan sesuatu hal yang beliau nyatakan menjadi sebuah mitos, dan mitos ini memiliki konotasi terhadap ideologi tertentu. Skema pemaknaan mitos itu oleh Barthes digambarkan sebagai berikut:

\begin{tabular}{|c|c|c|}
\hline $\begin{array}{l}\text { 1. Penanda } \\
\text { Benda dari kain untuk } \\
\text { penutup kepala dengan } \\
\text { bagian depan lebih menonjol }\end{array}$ & $\begin{array}{l}\text { 2. Petanda } \\
\text { Topi }\end{array}$ & \\
\hline $\begin{array}{r}\text { 3. Tanda } \\
\text { Topi } \\
\text { I. PENANDA }\end{array}$ & & \begin{tabular}{l}
\multicolumn{2}{l}{ II. PETANDA } \\
Benda untuk \\
menjunkan gaya \\
hidup gaul
\end{tabular} \\
\hline
\end{tabular}

Gambar 1. Semiotika Model Roland Barthes

Sumber: Roland Barthes (dalam Storey, 1994) 
Secara operasional dalam penelitian ini semiotika diterapkan dengan melakukan kajian terhadap tanda-tanda yang terdapat pada iklan Thermolyte Plus. Iklan Thermolyte Plus yang diteliti ditempatkan menjadi teks yang merupakan rajutan yang berasal dari berbagai tanda. Tanda-tanda yang terdapat dalam bentuk gambar, tulisan maupun suara diambil dari shoot dan scene yang ada dalam iklan Thermolyte Plus. Pada tahap hasil penelitian ini, peneliti menyajikan pemaknaan secara denotatif dan konotatif, dimana selanjutkan akan dilanjutkan dengan pembahasan yang menganalisis temuan penelitian menggunakan intertekstualitas dengan aneka macam teori yang relevan

\section{HASIL DAN PEMBAHASAN}

HASIL

Bagian ini memaparkan hasil dengan menampilkan pemaknaan iklan Thermolyte Plus secara denotasi (primary signification) dan konotasi (secondary signification).

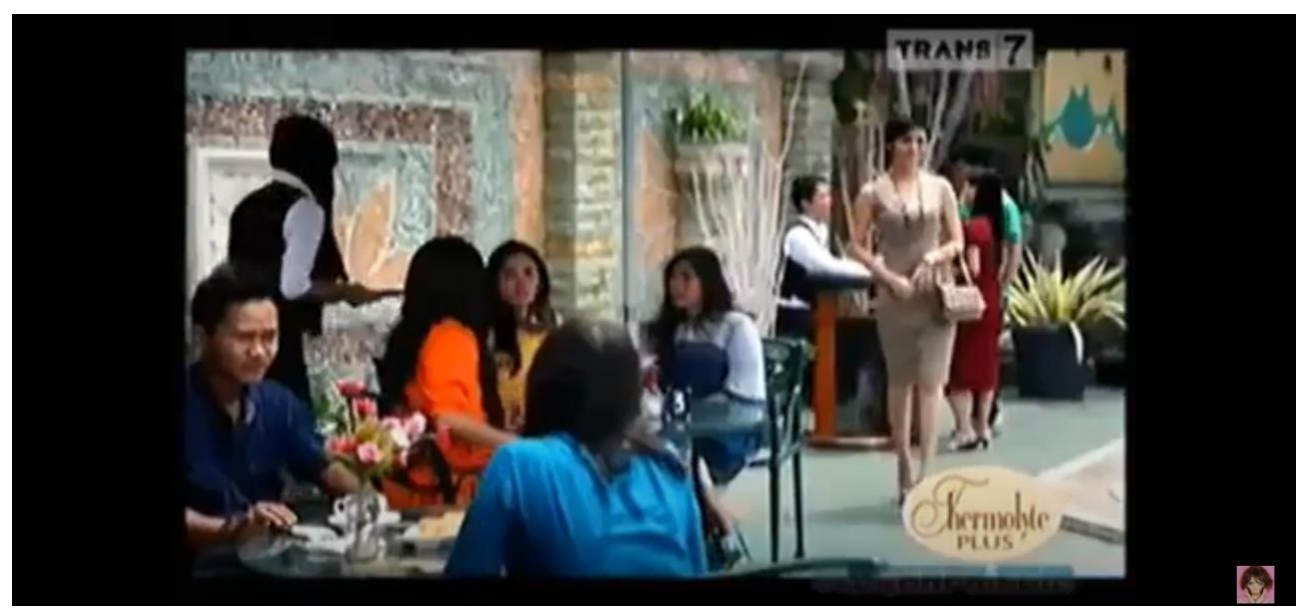

Gambar 2. Iklan Thermoyte Plus Fenita Arie

Makna denotasi: Penanda dalam iklan ini adalah perempuan berbaju coklat muda yang ketat sesuai bentuk tubuh, memakai kalung, membawa tas . seorang perempuan langsing menggunakan pakaian yang ketat dan memperlihatkan bentuk tubuh yang langsing tengah berjalan melewati sekumpulan perempuan lainnya. Sekumpulan perempuan tersebut berbincang-bincang mengenai bentuk tubuh perempuan dengan pakaian dengan tubuh yang diidam - idamkan para perempuan tersebut. Dalam perbincangannya para perempuan saling memberikan opininya terhadap bentuk tubuh perempuan tersebut. Petanda adalah perempuan yang berbaju coklat yang ketat menjadi perhatian dari perempuan lain, dan sekaligus mengundang kecemburuan dari perempuan yang lain.

Makna konotasi: Merasa percaya diri dan cantik dengan tubuh langsing. Pada screenshot yang ditampilkan diatas menampilkan perempuan dengan tubuh langsing dan elegan tengah berjalan melewati sekumpulan perempuan lainnya. Pada adegan ini perempuan dengan memakai pakaian ketat dan memperlihatkan lekukan tubuhnya dengan ditambah menggunakan tas dan beberapa aksesoris, wanita tersebut berjalan dengan percaya diri melewati beberapa perempuan lainnya. Padahal perempuan lainnya sedang membicarakan tentang tubuh perempuan tersebut. Fenita Arie yang menjadi peran perempuan bertubuh langing tersebut menggunakan pakaian ketat dengan percaya dirinya dikarenakan ia ingin menampilkan bentuk tubuhnya yang ideal walaupun sudah mempunyai dua anak. Dengan pembawaannya yang santai dan kalem mampu membuat perempuan lainnya bisa merasa iri terhadap penampilannya, ditambah dengan menggunakan baju ketat berwarna coklat dan sepatu berhak tinggi membuat tampilannya semakin elegan.

Mitos: Rasa percaya diri dan merasa cantik dengan tubuh langsing. Menurut Anthony (Gufron \& Rini, 2011) kepercayaan diri ialah sikap pada diri individu yang dapat menerima kenyataan, dapat 
mengembangkan kesadaran diri, berpikir positif, memiliki kemandirian, dan mempunyai kemampuan untuk memiliki serta mencapai segala sesuatu yang diinginkan. Memiliki tubuh yang langsing tidak sepenuhnya akan selalu merasa percaya diri tampil dimuka umum. Begitu pula dengan merasa cantik. Sebenarnya kepercayaan diri itu tumbuh berdasarkan pola pikir dan juga dukungan dari pihak luar mengenai bentuk tubuh perempuan. Citra tubuh yang lebih positif mencerminkan individu lebih puas terhadap dirinya sehingga dapat meningkatkan rasa percaya diri (Sutriandewi, 2003)

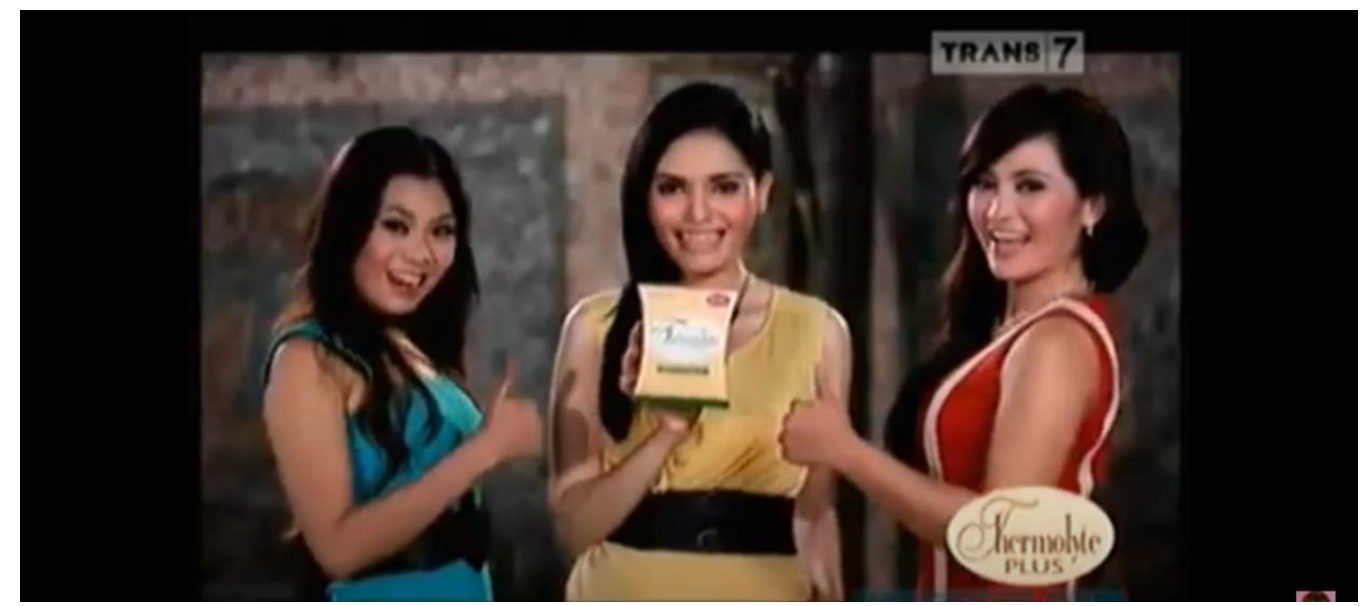

Gambar 3. Iklan Thermoyte Plus Fenita Arie

Makna denotasi: Penanda dari gambar ini adalah tiga orang perempuan yang yang menggunakan pakaian yang menonjolkan bentuk tubuh mereka berwarna merah, kuning, dan biru, menggunakan sabuk, kalung dan anting dengan ekspresi wajah yang ceria dan bahagia, sembari satu orang menunjukan Thermolyte Plus sedangkan dua lainnya mengacungkan jempol mereka dan mengatakan bahwa mereka sudah kehilangan berat badan dan memiliki tubuh yang ramping. Penanda adalah tiga orang perempuan yang bertubuh langsing setelah mengkonsumsi Thermolyte Plus dan merasa puas dengan perubahan bentuk tubuhnya.

Makna konotasi: Percaya diri setelah mengkonsumsi Thermolyte Plus. Pada sceen ini menampilkan makna bahwa perempuan yang memiliki tubuh ramping akan lebih memiliki rasa percaya diri terutama dalam hal berpakaian. Bentuk badan menjadi salah satu penunjang penampilan bagi seorang perempuan, tidak hanya ramping tetapi badan juga harus terawat dan sehat. Pada awalnya, ketiga perempuan tersebut memiliki bentuk tubuh yang tidak ramping atau bertubuh besar dan merasa iri dengan perempuan yang memiliki tubuh ramping sehingga demi menunjang penampilan, mereka akhirnya mengkonsumsi Thermolyte Plus untuk menghasilkan tubuh ramping dan menambah rasa percaya diri mereka.

Mitos : Memiliki rasa percaya diri karena mengkonsumsi Thermolyte Plus. Penampilan fisik menjadi faktor penting bagi individu sebagai representasi identitas dan visual yang ingin disampaikan kepada orang lain dalam interaksi sosial. Sebagian besar wanita membandingkan tubuhnya dengan visual atau stigma yang terbentuk dalam masyarakat. Standar kecantikan yang dianggap ideal dapat berubahubah sesuai perkembangan zaman dan kultur budaya yang berkembang. Memiliki penampilan fisik yang sesuai dengan standar kecantikan menjadikan seorang perempuan memiliki rasa percaya diri yang tinggi. Kepercayaan diri merupakan suatu keyakinan yang dimiliki seseorang bahwa dirinya mampu berperilaku seperti yang dibutuhkan untuk memperoleh hasil seperti yang diharapkan (Bandura, 1977). Para perempuan di gambar tersebut yang awalnya memiliki masalah kurangnya kepercayaan diri terhadap berat badan yang tergolong besar menjadi lebih percaya diri setelah mengkonsumsi Thermolyte Plus. 


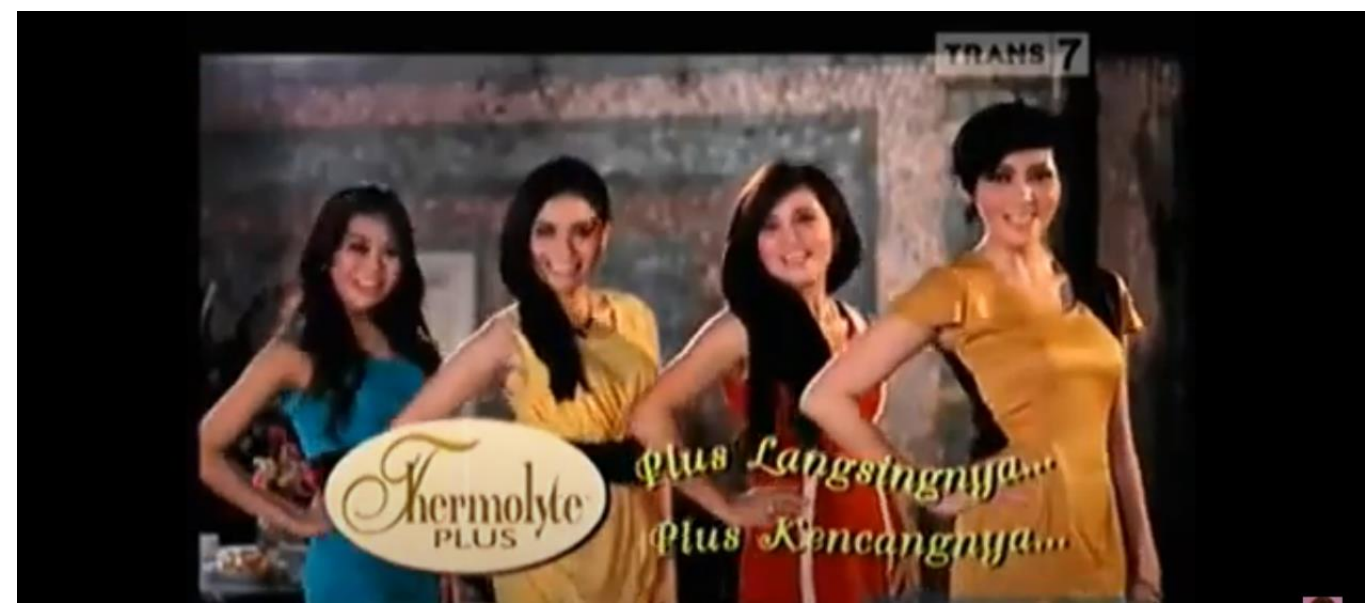

Gambar 4. Iklan Thermoyte Plus Fenita Arie

Makna denotasi: Penanda pada gambar ini adalah keempat perempuan yang berpose dan memakai pakaian yang menonjolkan bentuk tubuh mereka, berkulit putih sehat dan nampak tersenyum. Ditambah dengan adanya tagline yang berbunyi "plus langsinya, plus kencangnya".

Penanda adalah keempat perempuan diatas menunjukkan bahwa tubuh langsing, mulus, dan sehatnya merupakan tubuh ideal bagi seorang perempuan.

Makna konotasi: Tubuh langsing merupakan tubuh ideal. Tubuh yang langsing dan sehat merupakan dambaan bagi setiap perempuan sehingga banyak sekali dari mereka yang berlomba-lomba untuk membentuk tubuh yang ideal. Seperti yang dilakukan pada gambar sceen sebelumnya, dimana para perempuan tersebut merasa bahwa tubuh mereka memiliki berat badan yang berlebih sehingga mereka memutuskan mengkonsumsi Thermolyte Plus untuk mendapatkan bentuk tubuh langsing yang dimana masuk pada kategori bentuk tubuh ideal. Sehingga secara tidak langsung, tubuh langsing dan sehat merupakan stereotype bentuk tubuh ideal di masyarakat yang harus dimiliki oleh perempuan.

Mitos: Tubuh langsing merupakan tubuh ideal. Para perempuan melakukan berbagai cara untuk mendapatkan bentuk tubuh proporsional. Tidak sedikit para perempuan yang melakukan perawatan dan mengeluarkan uang sampai berjuta-juta demi mendapatkan kecantikan dan tubuh yang ideal. Perempuan yang memiliki tubuh ideal dalam iklan sering kali di representasikan dengan perempuan yang memiliki kulit yang putih bersih, mulus, dan bertubuh langsing. 


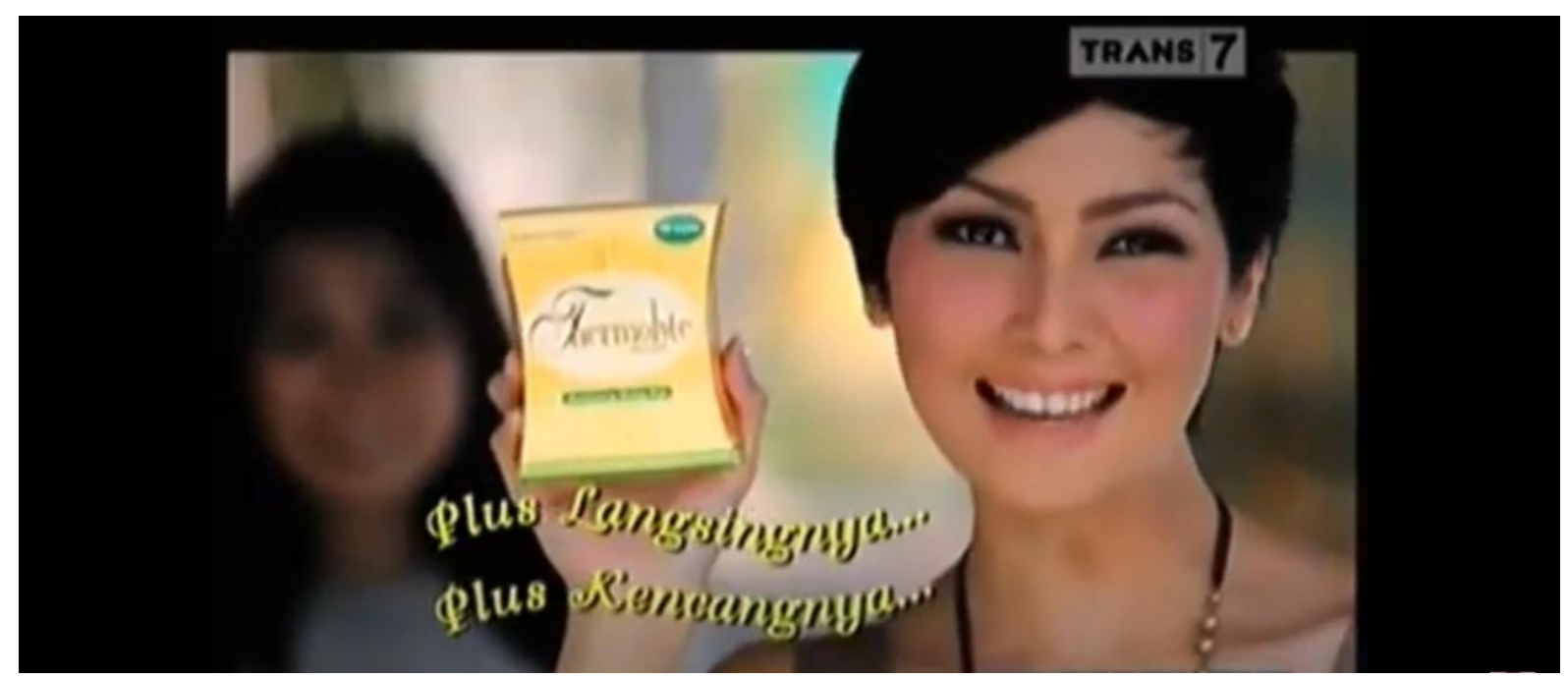

Gambar 5. Iklan Thermoyte Plus Fenita Arie

Makna denotasi: Penanda pada gambar ini adalah seorang perempuan yang menunjukan produk Thermolyte Plus dengan ekspresi wajah tersenyum ceria seolah-olah meyakinkan pada perempuanperempuan bahwa setelah mengkonsumsi produk Thermolyte Plus bisa membuat berat badan turun dan badan terlihat langsing ideal. Ditambah lagi dengan adanya tagline seperti di gambar scene sebelumnya bertuliskan "Plus langsingnya plus kencangnya" kata-kata tersebut menunjukan bahwa setelah mengonsumsi Thermolyte Pluss akan menurunkan berat badan sehingga menghasilkan tubuh langsing ideal dan sehat.

Makna konotasi : Tubuh langsing ideal dan sehat setelah mengkonsumsi Thermolyte Plus. Pada scene ini seorang perempuan menunjukan produk Thermolyte plus merupakan produk suplemen terpercaya, dan khasiat setelah mengonsumsi produk thermolyte plus akan mendapatkan tubuh langsing ideal dan sehat. Tidak hanya itu, hasil setelah mengkonsumsi thermolyte plus juga lebih efektif, cepat, dan juga aman untuk di konsumsi. Sehingga pada scene gambar diatas ajakan seorang perempuan kepada tiga perempuan lainya untuk mengonsumsi Thermolyte plus jika ingin memilki badan yang langsing ideal dan juga sehat.

Mitos : Narasi yang digunakan dalam iklan Thermolyte Plus "plus langsingnya, plus kencangnya" merupakan salah satu bentuk pemilihan kata yang bersifat persuasif, apabila ditujukan kepada masyarakat perempuan yang dimana kebanyakan dari mereka ingin memilki penampilan fisik dengan tubuh langsing ideal. Narasi tersebut juga dapat diartikan sebagai tanda bahwa setelah mengonsumsi produk Thermolyte Plus akan mendapatkan tubuh yang langsing ideal dan sehat yang telah menjadi dambaan setiap perempuan untuk meningkatkan rasa kepercayaan diri dan memenuhi standar kecantikan pada umunya.

\section{PEMBAHASAN}

Konsep perempuan dibentuk berdasarkan bagimana media membentuk suatu makna dalam bentuk pencitraan. Pencitraan ini media lakukan untuk memberikan pengaruh terhadap sejumlah ideologi yang akan dikedepankan. Ideologi bekerja dengan membiarkan individu- individu mengenali secara salah diri mereka yaitu melalui lingustik dan psikis. Dengan demikian Ideologi tidak menggambarkan dunia nyata, yaitu ideologi dipersepsikan sebagai relaita yang palsu (Strinati, 2007).

Perempuan sering kali digambarkan sebagai sebuah tayangan pada iklan yang didalamnya menonjolkan bagian dari perempuan. Dengan kecantikan yang ditonjolkan sehingga, membuat ideologi yang menonjol adalah gaya hidup. Melalui gaya, kebiasaan, perilaku dan penampilannya 
dalam media membuat perempuan menjadi sebuah objek dalam melakukan standarisasi bagi perempuan lainnya.

Media memiliki peran yang cukup besar dalam menyebarkan ideologi ini. Salah satunya yaitu kepercaya dirian perempuan. Ada dua faktor yang menjadi penyebab atas tinggi rendahnya rasa percaya diri perempuan yaitu faktor dari dalam dan faktor dari luar. Faktor dari luar tersebut meliputi pekerjaan, pendidikan, tingkat ekonomi hingga lingkungan sekitar. Sedangkan faktor dari luar yaitu kecerdasan, konsep diri, kepribadian, kecakapan berkomunikasi hingga bentuk tubuh. Faktor terpenting dalam percaya diri yaitu pada fisik dan bentuk tubuh (Putri, 2015).

Pandangan tersebut membuat perempuan beranggapan bahwa memiliki fisik dan bentuk tubuh yang ideal menjadi suatu tuntutan dalam menjalani hidup. Mereka beranggapan ketika seseorang memiliki penampilan fisik yang sempurna dan menarik akan memiliki kepribadian yang baik dan akan mendapatkan perlakuan yang lebih baik dibandingkan dengan perempuan yang tidak memiliki tubuh yang ideal seperti anggapan masyarakat banyak. Hal ini yang membuat para perempuan merasa saat mereka tidak memiliki bentuk tubuh yang ideal mereka tidak akan diterima oleh masyarakat.

Rasa tidak puas terhadap bentuk tubuh menjadi keyakinan individu bahwa penampilan mereka tidak memenuhi standar, sehingga banyak yang merendahkan tubuhnya. Hal ini yang akan menyebabkan individu merasa harga dirinya rendah, depresi hingga kecemasan yang berlebihan. Ketidakpuasan kepada bentuk tubuh mempertimbangkan adanya sebuah keinginan mempunyai tubuh yang lebih langsing (Odang, 2005)

Sesungguhnya, setiap negara memiliki standar kecantikan yang beda- beda. Survei kecantikan yang dilakukan oleh Diamond (dalam Cosmopolitan, 2012) menunjukkan bahwa secara umum wanita cantik adalah wanita yang memiliki wajah tirus, hidung mancung, berkulit putih bercahaya, rambut lebat, dan memiliki bentuk tubuh yang langsing. Tiara (2010) menyebutkan wanita bertubuh tinggi dan bertubuh kurus ceking menjadi standar ideal bagi para wanita dan dapat meningkatkan rasa percaya diri yang lebih tinggi dibandingkan dengan wanita yang memiliki tubuh besar dan jauh dari kategori tubuh ideal.

Praktek penandaan yang ada dalam iklan ini menunjukan adanya oposisi biner sebagai berikut.

Tabel 1. Oposisi Biner dalam Iklan Thermolyte Plus

\begin{tabular}{|l|l|}
\hline Tubuh Perempuan Ideal & Tubuh Perempuan Tidak Ideal \\
\hline Langsing & Gendut \\
\hline Padat & Berlemak \\
\hline Rambut panjang & Rambut tidak panjang \\
\hline Kulit putih & Kulit non putih \\
\hline
\end{tabular}

Sebuah penelitian yang dilakukan oleh Duarte, Matos, Stubbs (2017) para wanita bertubuh besar yang tidak memiliki kepercayaan diri cenderung memiliki rasa malu yang lebih tinggi, mengkritik diri sendiri (terutama kebencian terhadap diri sendiri), kurang yakin atas kemampuan diri, merasa lebih rendah daripada orang lain dan memiliki pandangan negatif terkait bentuk tubuh. Dampak lain dari kurangnya kepercayaan diri pada wanita bertubuh besar adalah dapat menyimpan rasa takut atau khawatir terhadap penolakan, sulit menerima realita diri (terlebih menerima kekurangan diri) dan memandang rendah kemampuan diri sendiri serta menanamkan harapan yang tidak realistik terhadap diri sendiri (Suryanie, 2005).

Seseorang yang memiliki kekurangan atau bentuk tubuh tidak proporsional, terlalu kurus atau terlalu gemuk, postur tubuh tinggi atau rendah akan lebih memiliki ketidakpercayaan diri ketika harus bertemu dengan orang baru. Hal ini dapat menciptakan rasa rendah diri, rasa malu atau tertutup (Afif, 2014). Kendala bagi kaum perempuan dalam memperjuangkan hak dan kedudukan yang layak dalam masyarakat adalah penampilan dari perempuan, yang dimana standarisasi kecantikan perempuan salah satunya memilki bentuk tubuh yang ideal dan memilki warna kulit putih. Perempuan- perempuan 
berusaha keras untuk mendapatkan tubuh ideal yang telah menjadi dambaan dan standarisasi kecantikan dikalangan masyarakat.

Perempuan akan berusaha menyesuaikan bentuk tubuh mereka dengan apa yang telah dikatakan pada kultur social masyarakat mengenai standar kecantikan tersendiri akan tetapi bentuk tubuh ideal perempuan sebagai standar kecantikan dapat berubah-ubah sesuai dengan zamannya dan juga terdapat berberapa negara di belahan dunia standar kecantikan perempuan justru semakin gemuk semakin cantik (Hidajadi, 2000).

Seperti yang terlihat dalam iklan Thermolyte Plus dimana memiliki tubuh yang bersih, sehat dan langsing merupakan gambaran bentuk tubuh yang ideal bagi seorang perempuan. Terlihat bagaimana iklan memperlihatkan perempuan menggunakan baju yang monjolkan bentuk tubuhnya, berkulit putih bersih, dan sehat. Terdapat pula adegan yang memperlihatkan bagaimana perempuan mengalami krisis kepercayaan diri dikarenakan memiliki berat badan yang berlebih dan merasa bahwa tubuh yang dimilikinya tidak sempurna sehingga menimbulkan rasa iri terhadap perempuan lain yang memiliki bentuk tubuh langsing, mulus, dan sehat. Iklan Thermolyte Plus membentuk suatu representasi dibenak perempuan bahwa bentuk tubuh yang ideal adalah bentuk tubuh yang ditampilkan dalam iklan.

Membicarakan representasi perempuan dalam iklan berarti membicarakan pula bagaimana media membentuk makna terhadap konsep perempuan melalui pencitraan dan sejumlah elemen representasi lainnya. Pencitraan yang dilakukan media terhadap suatu hal merupakan pencitraan yang telah diseleksi sebelumnya melalui pengaruh sejumlah ideologi yang hendak dikedepankan. Citra sebagai elemen representasi yang diproduksi dan didistribusikan oleh sebuah media merupakan penekanan makna tentang konsep suatu hal yang telah dimediasi oleh media terlebih dahulu. Informasi menjadi sarana media untuk merepresentasikan kepada khalayak mengenai apa dan bagaimana ikon perempuan dalam iklan sesuai dengan ideologi yang dikedepankan media bersangkutan. Iklan Thermolyte Plus membentuk makna mendapatkan bentuk tubuh yang langsing, mulus, dan sehat yang merupakan bentuk tubuh ideal bagi perempuan dengan rajin mengkonsumsi Thermolyte Plus sehingga sepenuhnya dapat menjadi seorang perempuan ideal dan menjadikan perempuan memiliki kepercayaan diri lebih terhadap tubuhnya (Mukti et al., 2015).

Persepsi tentang tubuh perempuan ideal merupakan standar kecantikan, citra tubuh ideal perempuan dalam iklan Thermolyte Plus yang menampilkan bahwa standar kecantikan perempuan memilki tubuh yang ideal. Hal tersebut tanpa disadari akan menciptakan kebanggaan tersendiri pada perempuan, dimana perempuan akan menjadi cantik apabila memilki tubuh ideal seperti apa yang di tampilkan pada iklan Thermolyte Plus setelah mengonsumsi produk tersebut.

\section{KESIMPULAN}

Dari hasil penelitian, dapat disimpulkan bahwa iklan Thermolyte Plus memberikan gambaran bagaimana seorang perempuan yang memiliki tubuh ideal. Dapat dilihat bahwa perempuan yang memiliki bentuk tubuh langsing, mulus, dan sehat menjadi dambaan bagi orang lain. Dapat dilihat juga bahwa seorang perempuan yang memiliki bentuk tubuh ideal menjadikannya sebagai suatu standar kecantikan. Sehingga memunculkan dalam benak masyarakat terkhusus masyarakat perempuan bahwa perempuan memang seharusnya memiliki bentuk tubuh langsing, mulus, dan sehat.

Dalam iklan Thermolyte Plus visualisasi yang digunakan dalam penyampaian pesan iklan menampilkan interaksi antar perempuan yang dimana pembuktian bahwa setelah mengonsumsi produk Thermolyte Plus akan memilki tubuh langsing ideal dan sehat. Setelah melakukan penelitian pada iklan Thermolyte Plus dapat disimpulkan, bahwa mitos yang terbangun dari sistem penandaan dalam iklan Thermolyte Plus pada scene pertama rasa percaya diri dan merasa cantik dengan tubuh langsing. Scene kedua memilki rasa kepercayaan diri setelah meminum Thermolyte Plus. Scene yang ketiga tubuh langsing merupakan tubuh yang ideal. Kemudian scene keempat narasi yang digunakan yaitu "plus langsingnya plus kencangnya" bersifat persuasif, bahwa setelah mengonsumsi Thermolyte 
Plus akan menghasilkan tubuh ideal dan sehat, hal tersebut menambah perempuan menjadi lebih percaya diri.

\section{PERSANTUNAN}

Artikel ini disusun sebagai bagian dari tugas kuliah Kajian Kritis Iklan di Program Studi Ilmu

Komunikasi Universitas Muhammadiyah Yogyakarta tahun akademik 2020/2021. Tim penulis menghaturkan terima kasih kepada Dr. Fajar Junaedi, dosen pengampu mata kuliah yang telah membantu dan mendukung penulis selama proses penelitian ini berlangsung sampai dengan terbitnya publikasi atas hasil penelitian ini.

\section{REFERENSI}

Brennan, M. A., Lalonde, C. E., \& Brain, J. L. (2010). Body image perceptions: Do gender different exist. Physic Journal of Undergraduate Research, 15(3), 130-1.

Diamond, N. (2005). Majalah Cosmopolitan: Standar kecantikan dunia itu berbeda.

Foucault, Mchel. (1997). Disiplin Tubuh (Bengkel Individu Modern), Sadur: P. Sunu Hardiyanta. Yogyakarta: LKiS.

Ferron. (1997). Citra tubuh pada remaja. Psychology Mania.

Ghufron, \& Rini. (2011). Teori-teori psikologi. Yogyakarta: Ar-Ruzz Media.

Hall, S. (1997). REPRESENTATION Cultural Representations. Representation: Cultural Representation and Signifying Practices, 1-63.

Hartley, J. (2003). A short history of cultural studies. A Short History of Cultural Studies, 1-189. https://doi.org/10.4135/9781446216934.

Laughey, D. (2007). Key themes in media theory. Key Themes in Media Theory, 1-29.

Mukti, I., Sultan, M. I., \& Bahfiarti, T. (2015). Semiotika Ikon Perempuan Pada Iklan Mobil Dalam Majalah Otomotif Autoexpert. Komunikasi KAREBA, 4(3), 344-359.

Muwarni, E. (2010). Konstruksi “Bentuk Tubuh Perempuan” Dalam Iklan Televisi. Jurnal Ilmu Komunikasi, 2(1), 10-19.

Nurfazrin, F., \& Raturahmi, L. (2016). Representasi Citra Perempuan Dalam Iklan WRP Versi Limited Edition. Jurnal Komunikasi, 2(1), 41-50.

Odang. (2005). Pengaruh Majalah terhadap Body Image dan Body Dissatisfaction pada Remaja Putri. Skripsi (tidak diterbitkan). Depok: Fakultas Psikologi Universitas Indonesia.

Pratiwi, O., \& Luthfianiza, L. (2020). Dari Kuning Langsat Menjadi Putih: Representasi Identitas Kulit Perempuan Ideal Indonesia Dalam Iklan Citra. Jurnal Audiens, 1(2).

Puspa, R. (2010). Isu Ras dan Warna Kulit dalam Konstruksi Kecantikan Ideal Perempuan Tahun, 23, 312-323.

Putri, S., \& Penulis, A. (2020). Representasi Tubuh Ideal Perempuan dalam Iklan WRP Versi Limited Edition. 1(2).

Putri. T. A. (2015). Hubungan antara body image dengan kepercayaan diri mahasiswi yang mengalamai obesitas. Skripsi (naskah publikasi). Surakarta: Fakultas Psikologi UMS.

Sataloff, R. T., Johns, M. M., \& Kost, K. M. (n.d.). Image and Representation_Key Concepts in Media Studies.

Sutriandewi. (2003). Hubungan Citra Raga dengan Perilaku Diet pada Remaja Putri. Skripsi (tidak diterbitkan). Yogyakarta: Fakultas Psikologi Universitas Islam Indonesia.

Strinati, D. (2003). Popular Culture Pengantar Menuju Teori Budaya Populer. Yogyakarta: Jalasutra.

Williams, K. (2003). Understanding Media Theory. 266.

Webb, J. (2009). Understanding Representation. London: SAGE Publication Ltd.

Wibowo, Indiawan Seto Wahyu. 2011. Semiotika Komunikasi. Jakarta:Mitra Wacana Media. 